\title{
DEVELOPMENT OF AUTOMATED NUTRIENTS COMPOSITION CONTROL FERTIGATION SYSTEM
}

\author{
Baljit Kaur and Dilip Kumar \\ Centre for Development of Advanced Computing (C-DAC) Mohali, India \\ baljeetgill31@yahoo.com and dilip@cdac.in
}

\begin{abstract}
Inefficient management of nutrient inputs has put a large constraint on the environment and human's health. Indiscriminate use of nitrogen and phosphorus fertilizers has led to ground water pollution. So the farmers has to pay close attention to nutrient management and incorporate the concept of balanced plant nutrition into their farming techniques. The balanced nutrition level to plant is provided by managing $\mathrm{pH}$ and Electrical conductivity level of fertilizer solution according to soil $\mathrm{pH}$ and electrical conductivity. Developed system comprises of two sensors to measure $\mathrm{pH}$ and EC of the fertilizer solution and soil. The output signals from the $\mathrm{pH}$ and EC electrode sensors are conditioned with the help signal conditioning cards and then interfaced to microcontroller through inbuilt ADC. Microcontroller will turn ON and OFF particular solenoid valve to pore the fertilizers into the mixing tank according to the $\mathrm{pH}$ and EC level in the mixing tank solution. LCD is used to display the computed results. $p H$ and EC level of fertilizer solution is maintained on the basis of output readings of EC and pH sensors.
\end{abstract}

\section{KEYWORDS}

Fertigation, pH, EC, Acidity, Alkalinity, Electrical conductivity, Nutrients.

\section{INTRODUCTION}

The history of the farmer started intensive cultivation of early-maturing, high yielding varieties without paying much attention to the soil-nutrient status and soil health. Continuous cultivation with inefficient management of fertilizers inputs has resulted in effect on the consumermalnutrition, environmental concerns and decrease in yields-qualitative and quantitative. Fertigation system provide balanced nutrition level to the plant by monitoring and modifying $\mathrm{pH}$ and EC level of fertilizers with respect to soil parameters using fertigation system [1]. The delivery of fertilizers in the field using irrigation water is known as 'Fertigation'. Its efficiency in nutrient management has greater control over crop performance and environmental effects. Optimum range of nutrients is critical for plant growth is provided by fertigation[2]. Optimum nutritional conditions can vary for different crops and for same crops at different times of their life cycle. For the same crops at different times of the year and the same crops under different environmental conditions [3]. The $\mathrm{pH}$ and EC (electrical conductivity) are the two important indices of fertigation [4]. They represent the whole quality and characteristics of fertilizers and water. It varies for different plants and soils. (a) $\mathrm{pH}-\mathrm{pH}$ give the information of acidity or alkalinity of solution. it is measured on a scale of $0-14$. $\mathrm{pH}$ reading of a solution below value 7 is considered acidic, while a $\mathrm{pH}$ reading above the value 7 is consider as basic. $\mathrm{A} \mathrm{pH}$ reading of 7 is neutral because there are equal concentrations of $(\mathrm{H}+)$ and $(\mathrm{OH}-)$ is ideal for many plants and spray materials.

$$
\mathrm{pH}=-\log [\mathrm{H}+](\text { neg. } \log \text { of the } \mathrm{H}+\text { conc. })
$$

DOI : $10.5121 /$ ijcsea.2013.3308 
$\mathrm{pH}$ level gives the availability of nutrients in the soil or fertilizer solution [5], [6]. $\mathrm{pH}$ range of fertilizers solution delivered in soil effects the soil properties. Calcium, Phosphorus, potassium and magnesium are unavailable to plants in acidic soil. Plants have difficulty in absorbing micronutrients like copper, zinc, boron, manganese and iron in basic soils; however their presence in soil can also be excessive and become toxic to plants. A higher quantity of bicarbonate ions are contained inbasic soil which affects the optimum growth in plants by interfering with the normal uptake of other ions [7], [9]. (b) Electrical Conductivity - Salinity of solution is measured by common way using electrical conductivity (EC) sensor. This sensor measures the electricity moves through a saltier solution, the electricity moves through it is directly proportional to the conductivity readings. EC is measured in $\mathrm{dS} / \mathrm{cm}$ (deciSiemens per centimeter) [10], [11], [12]. In all soils salts are naturally present additional salts build up in the soil by higher concentration of fertilizers applied . Under irrigation and inadequate drainage is also one of the cause of soil salinity. The salt concentration in the soil restricts a plant's ability to take up water from the soil. The higher EC value has toxic effect on plant's metabolism. EC affects the physical structure of soil. Salinity has positive effect in terms of soil aggregation and negative effect on plant's growth [13], [14], [15]. After this brief description, the paper is outlined as follows: In the Section 2, hardware description of fertilizer control system is discussed. Section 3 discussed about fertilizer selection. Section 4 and 5 are dedicated to working of sensors and algorithm of fertigation system respectivily,In Section 6, results for variation of $\mathrm{pH}$ and EC level of fertilizer solution with respect to ureas and sulpuric acid fertilizers are presented. Finally, conclusions work in progress and research agenda have been discussed in Section 7.

\section{RELATED WORK}

Saiful Farhan M. Samsuri, Robiah Ahmad and Mohamed Hussein are discussed about the automatic control of water, fertilizers and climate systems. Soluble fertilizers are required for the direct delivery of fertilizers through drip irrigation and pumping and injection systems to introduce the fertilizers directly into the irrigation. Accurate and uniform application of nutrients to the wet area is provided by fertigation, where the active roots are concentrated. It is possible to provide adequate nutrient quantity and concentration to their demand through the growing season of the crops. The design provides control of fertilizer mixing process using precise proportional pump injector flow rate with control time based injection at pre decided electrical conductivity (EC) value followed by plant nutrient uptake rate on time-based irrigation system for fertigation. The Planning of the irrigation system and nutrient supply to the crops according to their physiological stage of development, and consideration of the soil and climate characteristics brings good result in high yields and high quality crops. [1].

Michael Treeby, Steven Falivene, Mark Skewes proposed the delivery of dissolved fertilisers to the roots of crops in the field using irrigation water is called as fertigation. Fertigation is gaining popularity because of its efficiencies in nutrient management, time and labour and potentially a greater control over crop performance and environmental effects. Supply of dissolved mineral nutrients to plant roots has been a research tool for at least 100 years. Nutrient solution is mixture of water and dissolved nutrients. The concept had its first practical application in the 1940s when vegetables were grown in a soilless solution [2].

The fertigation refers to injecting fertilizer into an irrigation system. Accomplished by drip (trickle) injector system the concentrated fertilizer solution into the irrigation water was proposed by Dr. Richard G. Snyder and Dr. Amy M. Schmidt. A theory behind why fertigation has become the state of the art in vegetable nutrition is that apply the nutrients to plants in the correct dosage and at the right time for each specific stage of plant growth [3]. 
Cheng Wang, Chunjiang Zhao, Xin Zhang and Xiaojun Qiaoare are discussed about develops a general structure of a Precise Irrigation-Fertilization Machine. They Introduced the designing ideas of the hardware and software structure of Precise Irrigation- Fertilization Controller, which is the hard core of the machine. The manager and controller of sub-modules of the precise irrigation-fertilization controller are such as time module, memory module, valve control module, EC/PH measurement module and estate detection module, power module. The introduces the schematic diagrams and flow charts of the controller and main sub-modules of the system. [4].

\section{FERTILIZERS CONTROL SYSTEM}

Fertilizer tanks to deliver fertilizers and mixing tanks to mix fertilizers are used in this system as shown in figure 1 . The control units like solenoid flow valves operated by relays circuits are available that allow fertilizer tanks to be turned open at pre-set times to deliver fertilizer in mixing tank. Solenoid valve to be turned ON and OFF according to a pre-determined program that controls the valve according to the $\mathrm{pH}$ and $\mathrm{EC}$ signal of solution.

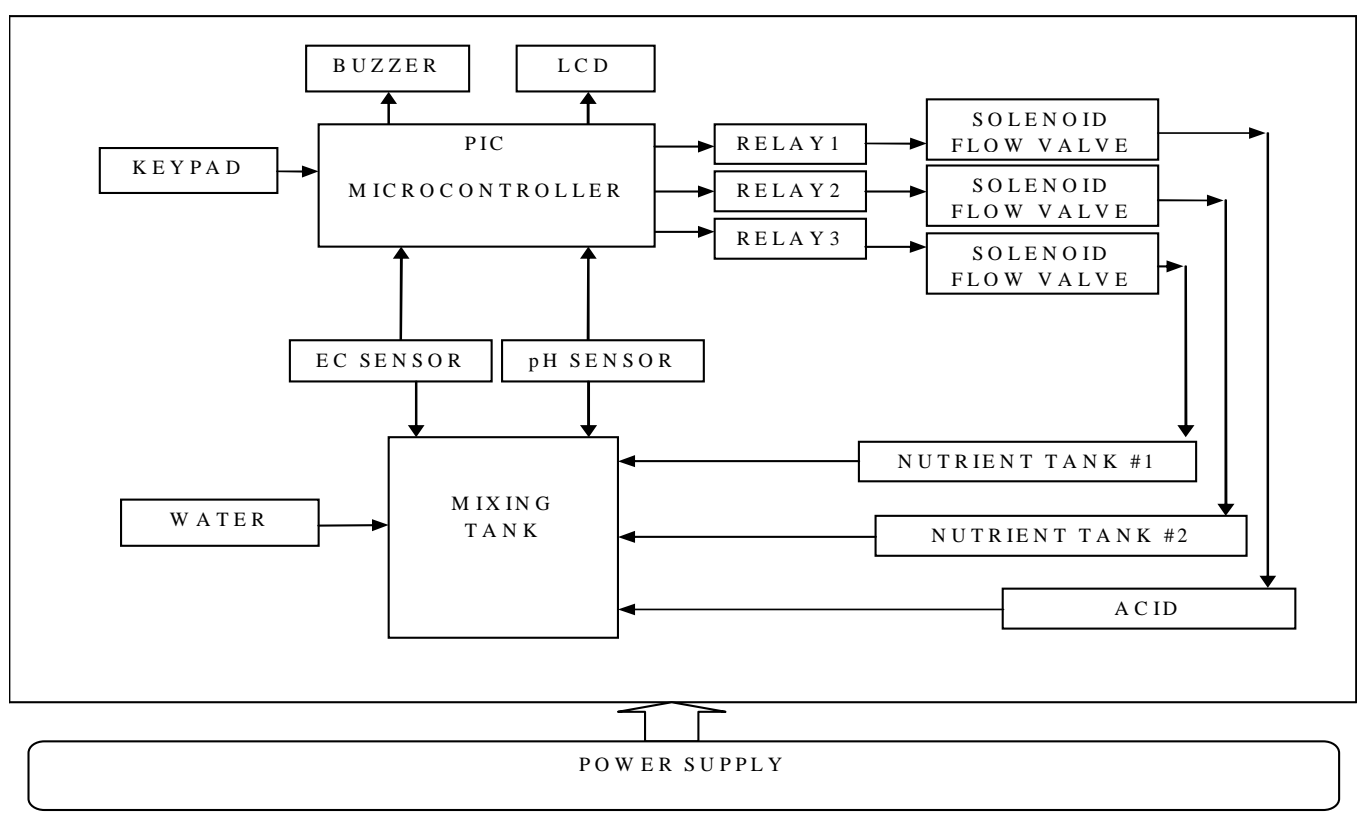

Figure. 1 Fertigation Control System

There is an equipment to monitor and modify the $\mathrm{pH}$ and electrical conductivity (EC) of the nutrient solution. $\mathrm{pH}$ readings are used to control availability of nutrients in the fertilizer solution. The EC values are used to give information about the quantity of fertilizer being injected into the fertilizer solution when the EC readings of the solution are higher than required amount that means high amounts of fertilizer has been injected in the fertilizer solution.

\subsection{General Description Of System}

\subsubsection{Keypad}

Keypad is a part of Human Machine Interface which is used to enter or select the $\mathrm{pH}$ and EC values. 
International Journal of Computer Science, Engineering and Applications (IJCSEA) Vol.3, No.3, June 2013

\subsubsection{Microcontroller}

The system is based on PIC16F877A programmable controller used to measure and maintained the $\mathrm{pH}$ and $\mathrm{EC}$ according to the required values entered through keypad. The PIC controller has inbuilt $\mathrm{ADC}$ to measure the analog signal received from $\mathrm{pH}$ and $\mathrm{EC}$ sensor.

\subsubsection{Relay}

Relay switch is electrically operated and used to operate the solenoid flow valve. The Current flowing through the coil of the relay creates a magnetic field which attracts a lever and changes the switch contacts.

\subsubsection{Relay Driver}

For relay's interfacing with microcontrollers or other low current digital ICs, a power or current amplifier circuit is required known as relay driver circuits. Diodes and optocouplers are used to operate relay using microcontroller.

\subsubsection{Solenoid valve}

A solenoid valve is an electromechanically operated valve which is most frequently used to control fluids flow. Their tasks are to shut off, release, dose, distribute or mix liquid form solutions.

\subsubsection{Mixing Tank}

A mixing tank contain the fertilizer solution mixed with water dropped through solenoid valves from other fertilizers tanks.

\subsubsection{Nutrient Tanks}

Fertilizer tanks contain the different types of fertilizer to make solution acidic or alkaline.

\subsubsection{Buzzer}

A buzzer is an audio signal producing output device. In this system buzzer is used for the indication of completed process.

\subsubsection{Liquid Crystal Display (LCD)}

The LCD is used to display the computing results. The main features of Hitachi 44780 LCD are: 16 X 2 displays used for alphanumeric characters \& based on ASCII codes.

\section{FERTILIZERS SELECTION}

The main factors affecting fertilizers composition are the plant characteristics, soil characteristics, irrigation water quality and growing place. Major nutrients nitrogen $(\mathrm{N})$, phosphorus $(\mathrm{P})$ and potassium $(\mathrm{K})$ are supplied to plant through fertigation process. However calcium $(\mathrm{Ca})$ and magnesium $(\mathrm{Mg})$ are sometimes supplied in the field. When potassium sulphate and magnesium sulphate are used to supply $\mathrm{K}$ and $\mathrm{Mg}$ respectively, soil also gets Sulphur (S) in addition. The micronutrients such as boron $(\mathrm{B})$, iron $(\mathrm{Fe})$, manganese $(\mathrm{Mn})$, zinc $(\mathrm{Zn})$, copper $(\mathrm{Cu})$ and 
molybdenum (Mo) are generally applied as foliar sprays because they are required in small amounts.

Fertilizers to manage $\mathrm{pH}$ and $E C$ - Soil $\mathrm{pH}$ is altered by the application of fertilizers solution. Ammonium forming fertilizers make solution acidic while nitrate forming fertilizers contains basic ions and are less acid forming make solution alkaline. Ammonium and ammonium forming fertilizers (ex. urea) are used to decrease $\mathrm{pH}$ level. Elemental sulphur, ammonium sulphate, and compounds such as iron or aluminium sulphates can reduce the soil $\mathrm{pH}$. Acidic soils are neutralized with the application of lime addition in soil. The requirement of lime dependent upon the buffering capacity of the soil. The Saline soils are also termed as alkaline soil [8]. Gypsum is the most common amendment used to remove excessive amounts of sodium ions (Na+) from soil profile and improve saline soil. Gypsum is used to improve saline and alkaline soil having $\mathrm{pH}$ range up to 9.0. Sulphur, iron sulphate, iron pyrite used for soil having $\mathrm{pH}$ level 8.0-9.0, lime stone is used having $\mathrm{pH}$ less than 8.0. Mixing Of Fertilizer-The mixing container with 50 $75 \%$ of the required water should be used in the mixture if mixing dry soluble fertilizers. Always put acid into water rather than water into acid. When chlorinating water with chlorine always add chlorine to water and not vice versa. aAcid or acidified fertilizers can not be mixed with chlorine.

\section{WORKING OF pH AND EC SENSOR}

\subsection{Measuring pH}

Fertigation solution $\mathrm{pH}$ is measured using $\mathrm{pH}$ electrode. The output signal of $\mathrm{pH}$ electrode is in milli-volts $(\mathrm{mV})$. The working of $\mathrm{pH}$ electrode is based on the principle that a potential is developed when two solutions of different $\mathrm{pH}$ comes in contact through a thin glass membrane. The $\mathrm{pH}$ electrode is consists of glass electrode and reference electrode the potential between these two electrodes. The glass ball has specific surface properties which is used at the end of the $\mathrm{pH}$ electrode is capable of ion exchange. The reference electrode remains at the constant potential. The $\mathrm{pH}$ electrode is a bipolar sensor i.e., $\mathrm{pH}$ electrode has positive as well as negative output values and has linear dependency on the $\mathrm{pH}$ of solution. The $\mathrm{pH}$ electrode gives voltage of $414 \mathrm{mV}$ at $\mathrm{pH}$ of 0 (i.e. Strong Acids) and $-414 \mathrm{mV}$ at $\mathrm{pH}$ of 14 (i.e. Strong Bases). $\mathrm{pH}$ electrode output voltage for acids is positive and negative for bases. For neutral solutions with $\mathrm{pH}$ of 7 , the output of $\mathrm{pH}$ electrodes is $0 \mathrm{mV}$ ideally. The $\mathrm{pH}$ electrode sensitivity is $59.15 \mathrm{mV} / \mathrm{pH}$. The output of $\mathrm{pH}$ electrode at various $\mathrm{pH}$ values is shown in Figure 2. By this Formula

$\mathrm{mv}=(7-\mathrm{pH})\left(54.2+\mathrm{T}^{*} 0.2\right)$

Where,mv=Input voltage produced by $\mathrm{pH}$ electrode

$\mathrm{pH}=$ varying from $0-14$

$\mathrm{T}=$ Temperature in degree Celsius

\begin{tabular}{|l|l|l|l|l|l|l|l|l|l|l|l|l|l|l|l|}
\multicolumn{10}{c|}{ Acids } \\
\hline $\mathrm{pH}$ & 0 & 1 & 2 & 3 & 4 & 5 & 6 & 7 & 8 & 9 & 10 & 11 & 12 & 13 & 14 \\
\hline $\begin{array}{l}\mathrm{pH} \quad \text { sensor } \\
\text { output(mV) }\end{array}$ & 414 & 355 & 296 & 237 & 177 & 118 & 59 & 00 & -59 & -118 & -177 & -237 & -296 & -355 & -414 \\
\hline
\end{tabular}

Figure 2. pH electrode output at different $\mathrm{pH}$ values 
International Journal of Computer Science, Engineering and Applications (IJCSEA) Vol.3, No.3, June 2013

The measurement of $\mathrm{pH}$ is sensitive to temperature of aqueous solution. The sensitivity of $\mathrm{pH}$ electrode is directly proportional to temperature. The $\mathrm{pH}$ electrode sensitivity with temperature is given as

$\mathrm{pH}$ electrode sensitivity $=00.000198 \times \mathrm{T} \mathrm{V} / \mathrm{pH}$

Temperature in degree Celsius is converted into degree Kelvin by

$\mathrm{T}(\mathrm{K})=\mathrm{T}(\mathrm{C})+273.13$

$\mathrm{T}(\mathrm{K})=$ Temperature in degree Kelvin

$\mathrm{T}(\mathrm{C})=$ Temperature in degree Celsius.

Temperature changes the chemical activity. The $\mathrm{pH}$ electrode transfer function at the temperatures $100 \mathrm{deg} \mathrm{C}, 25 \mathrm{deg} \mathrm{C}$ and $0 \mathrm{deg} \mathrm{C}$ are shown in figure 3, generally most measurements of $\mathrm{pH}$ include a temperature correction to a standard temperature of 25 degrees $\mathrm{C}$. The signal generated by the $\mathrm{pH}$ sensor has a linear relationship with the $\mathrm{pH}$ of the aqueous solutions.

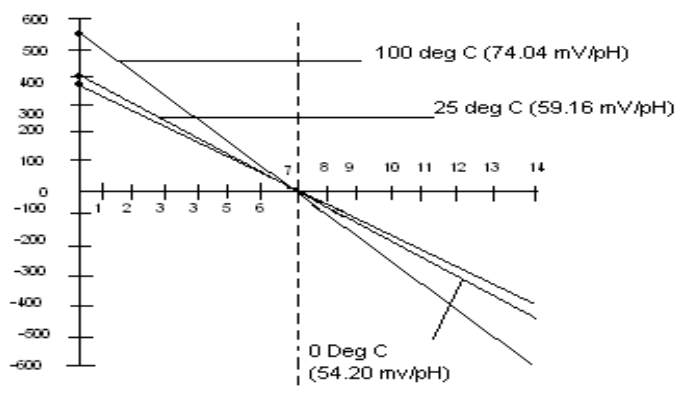

Figure 3. pH electrode transfer function

$\mathrm{pH}$ sensor is interfaced to microcontroller through unity gain differential amplifier for impedance matching.

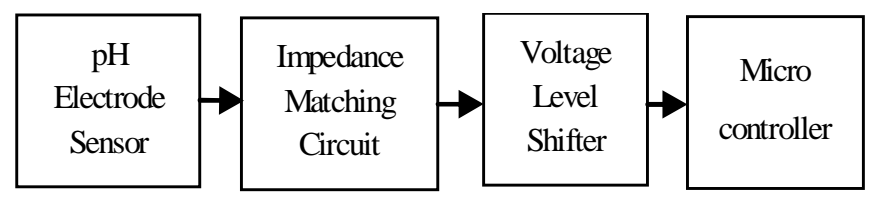

Figure 4. Working of $\mathrm{pH}$ Sensor

It is necessary to shift the negative signal from $\mathrm{pH}$ sensor towards positive side. This is done with the help of voltage divider circuit as shown in figure 5 the output of differential amplifier is given to voltage divider circuit.

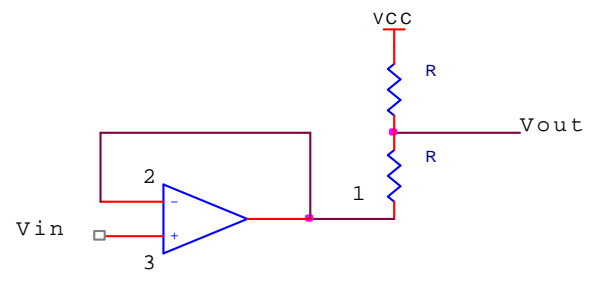

Figure 5. Differential amplifier for impedance matching 
$\mathrm{pH}$ electrode's output is applied to one of the input terminal of differential amplifier and other terminal is provided with a reference signal.

\subsection{Measuring EC}

The electrical conductivity of a solution is measured by determining the resistance of the solution between two flat or cylindrical electrode separated by a fixed distance. The resistance is measured by a conductivity cell. An alternating voltage is used in to avoid electrolysis. The parameter cell constant of conductivity cell is used to convert the conductance measured by conductivity cell and is defined by

$\mathrm{K}=\mathrm{d} / \mathrm{A}$

$\mathrm{K}=$ Cell constant or Cell factor.

$\mathrm{d}=$ Distance between the electrodes

$\mathrm{A}=$ Area of the electrodes

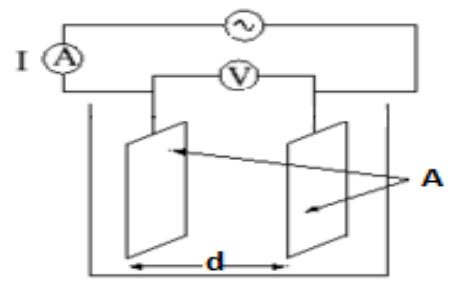

Figure 6. Parameters of conductivity cell

Measurement of conductivity is done by measuring the conductance of fertilizer solution or soil extract. The conductance so measured is multiplied by the cell constant to get conductivity of soil and is given by

$\mathrm{C}=\mathrm{G} \times \mathrm{K}$

$\mathrm{C}=$ Conductivity

$\mathrm{G}=$ Measured Conductance

$\mathrm{K}=$ Cell Constant Conductivity of solutions cannot be measured by applying a DC signal to conductivity cell, because if the DC signal is passed through the conductivity cell and dipped in the aqueous solution, it will rip the ions apart and a constant changing reading will be obtained.

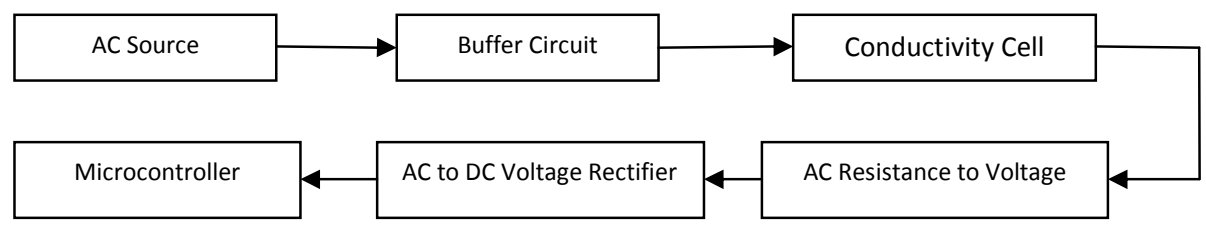

Figure 7. working of conductivity meter

Figure 7. shows the working of conductivity meter. Conductivity sensor is interfaced to the microcontroller through the standard interfacing card which provides sinusoidal AC excitation to the conductivity cell, buffer circuit is used to avoid loading effects. AC resistance of solution 
between two electrodes measured by Conductivity cell is inversely proportional to the conductance of solution shown in Figure 8.

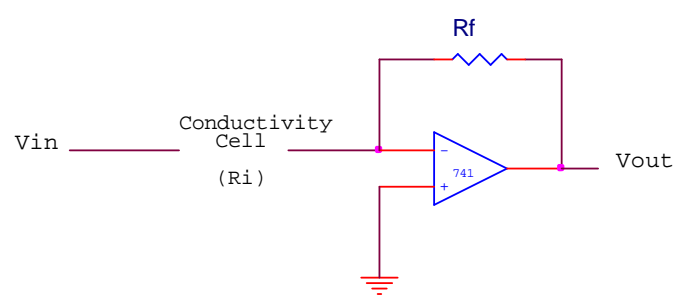

Figure 8. Resistance to Voltage Converter

$$
\text { Vout }=\frac{R_{f}}{R_{i}} \text { Vin }
$$

$\mathrm{R}_{\mathrm{i}}=$ Resistance of the solution between two electrodes of conductivity cell

$\mathrm{R}_{\mathrm{F}}=$ Feedback Resistance

$\mathrm{V}_{\text {out }}=$ output $\mathrm{AC}$ voltage

$\mathrm{V}_{\text {in }}=$ input $\mathrm{AC}$ voltage

LM741 op-amp generates AC voltage signal proportional to conductivity of solution. Using AC to $\mathrm{DC}$ converter AC voltage converted into DC voltage.

\section{ALGORITHM}

Figure 9 dipicts the flow chart of fertigation control system algorithm. The main steps of flow chart are given as following.

1) Enter the soil parameters $\mathrm{pH}$ and $\mathrm{EC}$ either manually through keypad or the soil parameters determined by the system from soil sample with the help of sensors.

2) Enter the desired parameters of crop manually or select the predefined crop mentioned in the system.

3) Comparison of the desired parameters of crop with actual parameters of soil is done using microcontroller.

4) Fertilizer control system will monitor and modify the $\mathrm{pH}$ and $\mathrm{EC}$ of mixing tank solution by taking fertilizers from selected fertilizer tanks.

5) Select the parameter which is to be modified $\mathrm{pH}$ or EC.

6) As per the selected parameter microcontroller will get the signal from sensor.

7) Again comparison of the actual value of fertilizer solution with desired value of fertilizer solution is done using microcontroller.

8) On the basis of the comparison done in step7 microcontroller will turn the particular solenoid valve either on or off and corresponding fertilizer from the fertilizer tank will be poured in the mixing tank for certain time.

9) If desired parameters achieved the system will stop with the indication of buzzer else the system will go back to the step 7 and step 8 in continuous manner until the desired value is achieved. 


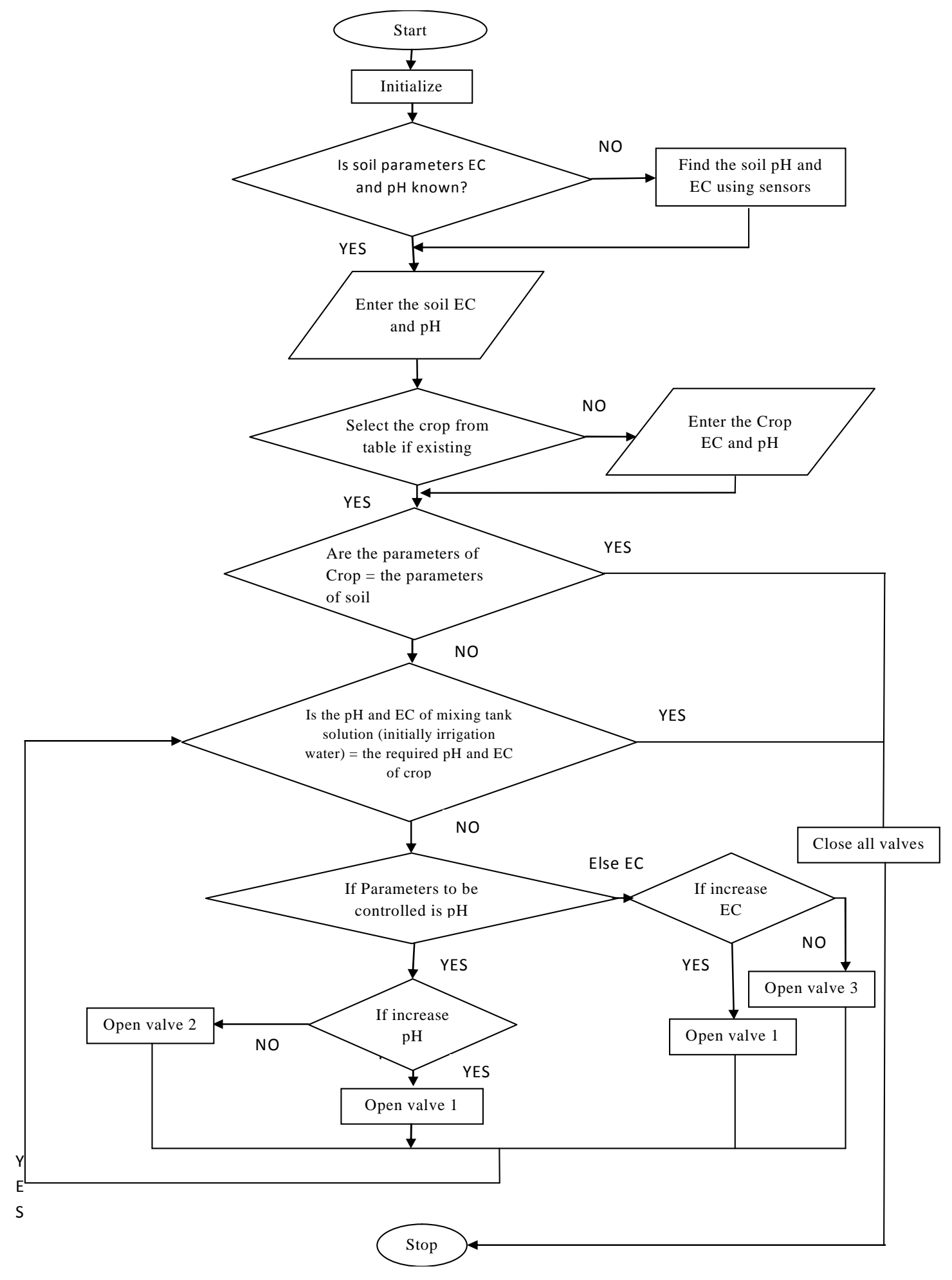




\section{RESULTS}

Figure.9 Algorithm of the system

The developed system was tested using urea and nitric acid. The control unit present satisfactory operation of all the valves as per the programming. Bicarbonates, carbonates and hydroxides increase the alkalinity of water. Phosphoric, nitric and sulfuric acids are the most commonly used to decrease the $\mathrm{pH}$ and make the solution acidic. Fertilizers are forms of salts and therefore electirical conductivity rise with addition of fertilizers.

\section{1 $\mathrm{pH}$ characterstics}

Adition of urea to water did not have significant effect on acidic or alkaline behavior of water but nitric acid reduce the $\mathrm{pH}$ level make the solution acidic as shown in figure 10.

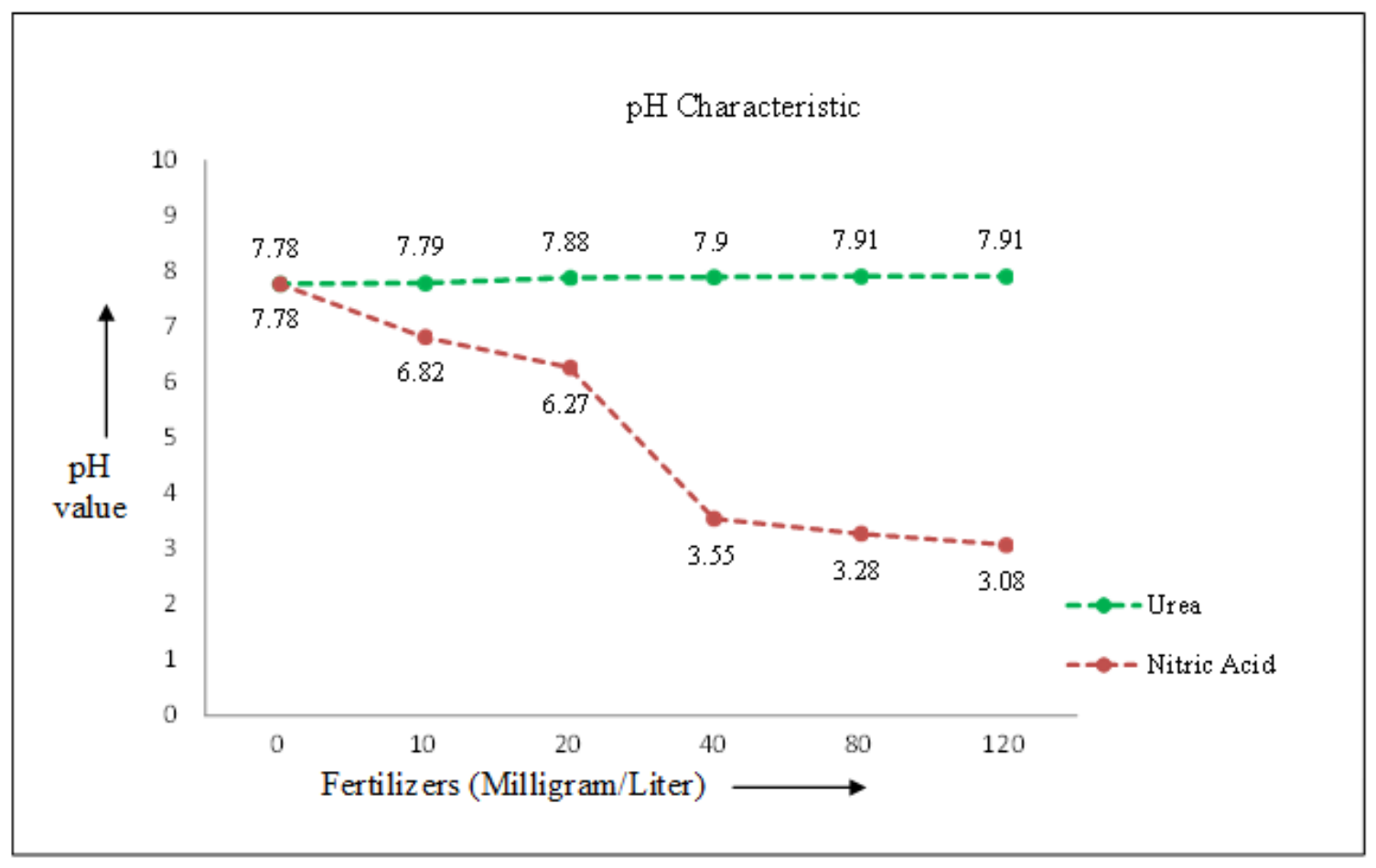

Figure. $10 \mathrm{pH}$ characterstics according to the addition of urea and nitric acid fertilizers

\section{2 electrical conductivity characterstics}

Addition of urea and nitiric acid rise the electrical conductivity level of solution as shown in figure 11 . 


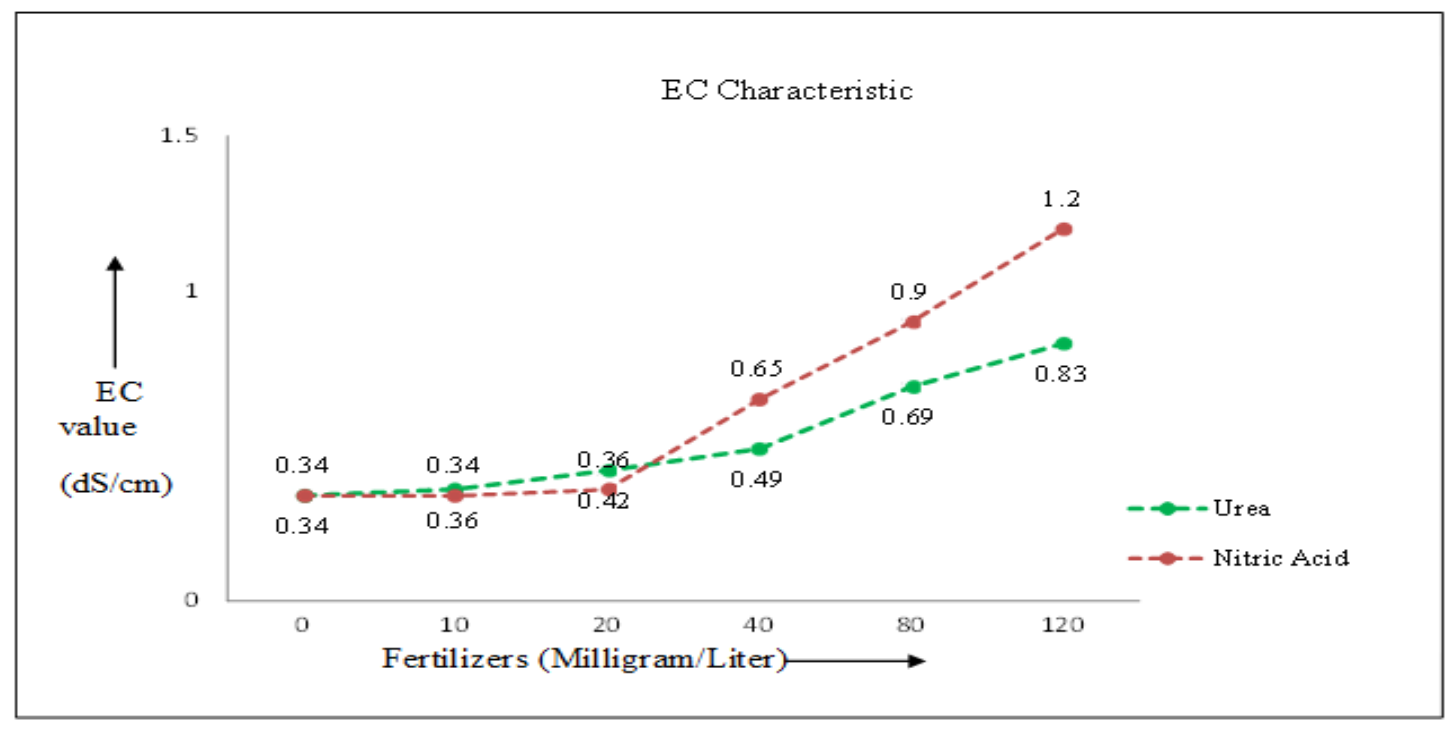

Figure.11 EC characterstics according to the addition of urea and nitric acid fertilizers

\section{CONCLUSIONS}

The developed nutrients composition control system will automatically monitor EC and $\mathrm{pH}$ level of fertigation solution with respect to the parameters of soil. This will reduce the effect of high concentration of salt and minimize the $\mathrm{pH}$ problems in the soil by spreading fertilizers in the controlled manner and also will improve the productivity. The result of solution's $\mathrm{pH}$ measurement gives the information about availability of nutrients in solution and EC readings are indicative of amounts of fertilizers being injected into the fertigation system. This work aims to develop a system that can measure these parameters ( $\mathrm{pH}$ and EC) with the help of electrical sensor and maintained their level using required amount of fertilizers. The fertilizer quantity is limited according to the crop requirement.This system may help in the efficient use of fertilizer and also helps to improve soil structure and environment. So this indigenously developed low cost auto fertilizer control system ensures better returns to human's health and environment.

\section{ACKNOWLEDGEMENTS}

We would like to extend a special thanks to C-DAC Mohali for providing us means to carry out our research work in meticulous way. We are also grateful to MHRD, Govt of india for providing us a platform to do our research work.

\section{REFERENCES}

[1] Samsuri, Saiful Farhan M., Robiah Ahmad, and Mohamed Hussein, (2010) "Development of Nutrient Solution Mixing Process on Time-based Drip Fertigation System" In Mathematical/Analytical Modelling and Computer Simulation (AMS), Fourth Asia International Conference, pp. 615-619. 
[2] Treeby, Michael, Steven Falivene, and Mark Skewes, (2012). "primefacts."

[3] Snyder, Richard Glen, and Amy Millmier Schmidt,(2011) Fertigation: "The Basics of Injecting Fertilizer for Field-grown Tomatoes". Mississippi State University Extension Service.

[4] Wang, Cheng, Chunjiang Zhao, Xin Zhang, Xiaojun Qiao, and Yinghua He, (2007) "Research and Exploitation of Precise Irrigation-Fertilization Controller." In Industrial Electronics and Applications, 2nd IEEE Conference, pp. 172-175.

[5] de Caritat, Patrice, Michelle Cooper, and John Wilford, (2011) "The pH of Australian soils: field results from a national survey." Soil Research 49, no. 2 173-182.

[6] National Instruments, (2006) " $\mathrm{pH}$ measurement tutorial", Available: http://zone.ni.com/devzone/cda/tut/p/ id / 2870.

[7] Agronomy Fact Sheet Series,( 2005) "Soil pH for Field Crops", Nutrient Management Spear Program, Department of Crop and Soil Science, Cornell University Corporative Extension, Fact Sheet Number 5.

[8] G.E. Cardon, J.G. Davis, T.A. Bauder, and R.M. Waskom,(2003) "Managing Saline Soils", Colorado State University Cooperative Extension. www.ext.colostate.edu

[9] Tony Provin and J.L. Pitt, (2001) "Managing Soil Salinity", The Texas A\&M University System Extension publications E-60. Web at: http://texaserc.tamu.edu,.

[10] David H. Hardy,(2008) "Effect of fertilizer salts on soil pH", NCDA\&CS Agronomic Division.

[11] Robert Flynn,(2010) “Introduction to Soil Salinity”, New Mexico State University Gardening Advisor.

[12] Soil Quality Information Sheet(1998), "Soil Quality Indicators: pH", USDA Natural Resources Conservation Service.

[13] E.A. Hanlon , (2012) Soil pH and Electrical Conductivity: A County Extension Soil Laboratory Manual, University of Florida, IFAS Extensio.

[14] K.F. Golson, (2001) "Spatial Distribution of Soil Physical Properties under Various Forested and Agricultural Land Use management Practices", IEEE International Geosciences and Remote Sensing Symposium, 2001, Volume 5, pp 2088-2090.

[15] Soil Factsheet, (2001) "Soil pH”, British Columbia, Reference Number 637.100-1, Agdex: 534.

[16] M. Mark Loux, F. Anthony Dobbels, M. Jeff Stachler, G. William Johnson, Glenn R.W. Nice and T. Thomas Bauman, (2009)“Herbicide and Soil pH

\section{BIBLIOGRAPHY OF AUTHORS}

Baljit Kaur has done her bachelor of technology degree in Electronics and Communication Engineering with first division from Punjab Technical University Jalandhar in year 2011 and currently pursuing her Master of Technology degree in Electronics Product Design \& Technology from CDAC, Mohali. Her areas of interests are microcontrollers, Analog and Digital electronics. Her email-id is baljeetgill31@yahoo.com

Dilip Kumar received a B.E in Electronics and Telecommunication Engineering from Army Institute of Engineering and Technology (AIT), University of Pune, India and M.E in Electronics Product Design and Technology from Punjab Engineering College (PEC), Panjab University, Chandigarh, India in 2000 and 2003, respectively. Currently, he completed his PhD in Computer Science and Engineering at Maharishi Markandeshwar University (MMU), Ambala, India. He is involved in teaching and research activities at Centre for Development of Advanced Computing (C-DAC), A Scientific Society of the Ministry of Communication \& Information Technology, Government of India, Mohali, since 2005. His research interests include primarily in wireless sensor networks and embedded system. He has published $90+$ papers in international and national journal/conferences 